\title{
Effect of citric acid and acetic acid on the performance of broilers
}

\author{
M.Z. Islam, Z.H. Khandaker ${ }^{1}$, S.D. Chowdhury and K.M.S. Islam \\ Department of Poultry Science and ${ }^{1}$ Department of Animal Nutrition, Bangladesh Agricultural University, \\ Mymensing-2202, Bangladesh
}

\begin{abstract}
An experiment was conducted with commercial broilers to investigate the effects of feeding citric acid, acetic acid and their combination on their performance and to determine the economic competence of using citric acid and acetic acid in broiler rations. A total number of 108 one day old straight run broiler chicks were distributed to four dietary treatments i.e. $0 \%$ citric or acetic acid (A), $0.5 \%$ citric acid (B), $0.5 \%$ acetic acid (C) and their combinations $0.5 \%$ citric acid and $0.5 \%$ acetic acid (D). The birds were reared in cages. Body weight gains, feed conversion ratio (FCR), mortality, dressing yield and carcass characteristics were recorded. The performance showed significant increase in body weight gain $(P<0.05)$ when compared with the control during $0-5$ weeks of age on $0.5 \%$ citric acid $(B)$. Feed consumption increased $(P<0.05)$ at $2^{\text {nd }}$ and $3^{\text {rd }}$ weeks of age on $0.5 \%$ citric acid $(B)$. Feed conversion was found higher $(P<0.05)$ during $0-5$ weeks of age in treatment $B$ when compared to those of the other treatments. Carcass characteristics were not affected by dietary treatments. The highest mortality was found in treatment $A$ and treatment $C$ due to excessive hot. It may be concluded that use of $0.5 \%$ citric acid in the diet of broilers may have better performance in respect of live weight gain and feed conversion.
\end{abstract}

Keyword: Acetic acid, Citric acid, Broiler performance

\section{Introduction}

The feed additives have a number of beneficial effects like control of pathogenic microorganisms and enhance the growth of beneficial microorganisms (Shane, 1999). Antibiotics possess these beneficial effects but their use in the poultry industry has been intensively controversial because of the development of bacterial resistance and potential consequences on the human health. So, the alternatives to antibiotics are researched. Among these compounds, organic acids are promising alternatives (Hyden, 2000). Health of the gut is one of the major factors governing the performance of birds and thus, the economics of poultry production (Samik et al., 2007) and the profile of intestinal microflora play an important role in gut health. Dietary organic acids and their salts are able to inhibit microbial growth in the food and consequently to preserve the microbial balance in the gastrointestinal tract. In addition, by modifying intestinal $\mathrm{pH}$, organic acids also improve the solubility of the feed ingredients, digestion and absorption of the nutrients (Patten and Waldroup, 1988; Owings et al., 1990; Skinner et al., 1991; Adams, 1999).

Both, the feed industry and the poultry production sector, still suffer from huge losses due to the contamination of food with pathogenic bacteria and their related impacts in the animal, such as lower weight gains or even increased mortality. Poultry performance and feed efficiency are closely interrelated with the qualitative and quantitative microbial load of the host animal, including the load in the alimentary tract and in the environment. Organic acids like citric acid and acetic acid have been used in diets due to their positive effect on health and growth of bird. More recently, the ban on antibiotics as a growth promoter in the European Union and the resulting pressures on meat exporters around the world, have increased interest in organic acids to attain performance improvements in growing swine and poultry. As the uses of organic acids are becoming more acceptable to feed manufacturers, 
poultry producers and consumers, there is a growing interest in substituting them for antibiotic as growth promoters (Callsen, 1999). Citric acid and acetic acid are used as the substitute of antibiotic growth promoters in many countries of the world (Estieve et al., 1997). But use of citric acid and acetic acid as substitute of antibiotic growth promoter in Bangladesh is a new phenomenon. The effects of citric acid and acetic acid as substitute of antibiotic have not yet been evaluated much under Bangladesh condition. Therefore, the present study was undertaken to evaluate the effect of feeding citric acid and acetic acid and their combination on the performance of broiler and to determine its economic impact in broiler production.

\section{Materials and Methods}

The experiment was conducted with 108 one day old straight run broiler chicks (Hubbard Classic) for a period of 35 days. The chicks were randomly divided into 4 equal treatment groups ( $A, B, C$ and $D$ ) each having 27 chicks. Each treatment was subjected to 3 equal replications of 9 chicks each. The diets were formulated with commonly available feed ingredients is shown in Table 1 . The dietary treatments were A (control diet) and B, C and D were supplemented with $0.5 \%$ citric acid, $0.5 \%$ acetic acid and $0.5 \%$ citric acid $+0.5 \%$ acetic acid respectively with drinking water. Dry mash feed was supplied on adlibitum basis. Fresh clean drinking water was made at all the times. Adequate sanitary measures were taken during the experimental period. The birds were housed in cages of $120 \mathrm{~cm} \times 76 \mathrm{~cm}$.

Table 1. The ingredients and chemical composition of control diet

\begin{tabular}{|l|c|}
\hline Ingredients & Amount in the diet (\%) \\
\hline Maize & 51.75 \\
\hline Soybean meal & 42.00 \\
\hline Soybean oil & 4.00 \\
\hline Salt & 0.25 \\
\hline Di- Calcium Phosphate & 0.50 \\
\hline Calcium premix & 1.00 \\
\hline Vitamin-Mineral premix & 0.75 \\
\hline DL-Methionine & 0.15 \\
\hline Choline Chloride 60\% & 0.05 \\
\hline Chemical composition & Amount (\%) \\
\hline Dry matter & 85.00 \\
\hline Crude protein & 22.21 \\
\hline Crude fibre & 5.88 \\
\hline Ether extract & 1.76 \\
\hline Nitrogen free extract & 48.41 \\
\hline Ash & 6.96 \\
\hline ME(kcal/kg DM) & 3241.22 \\
\hline
\end{tabular}

Calculated according to Wiseman (1987)

At the age of day 4 and 14, birds were vaccinated against Infectious Bursal Disease (IBD) using Bursine-2. Chicks were also vaccinated with B.C.R.D.V on $8^{\text {th }}$ day. To evaluate the treatment effect, weight gain, feed conversion ratio, mortality, dressing percentage, economy of broiler production were recorded and calculated. At the end of experiment, two birds from each treatment were selected randomly to record the dressing yield, organs weight and cut up parts. Feed samples were analyzed for dry matter (DM), crude protein (CP), ether extract 
(EE), crude fiber (CF), nitrogen free extract (NFE), and total ash by following the method of AOAC (1990). Duplicate samples were analyzed and the average value was taken. Collected and calculated data were analyzed for analysis of variance (ANOVA). The significant differences were identified by LSD among the treatments.

\section{Results and Discussion}

\section{Body weight gain}

Effect of organic acids inclusion in broiler ration on live weight gain is presented in Table 2 . Significant $(P<0.05)$ difference in body weight of birds among the groups were observed at all ages. Birds on treatment $C$ showed lower $(P<0.05)$ weight gain than control group $(A)$ and treatment $B$ showed the highest $(P<0.05)$ weight gain. Treatment $D$ showed improved growth when administration of both citric acid in diets and acetic acid in water was done together. The growth retardation in treatment $C$ seemed to be a consequence of a depressed water intake induced by application of acetic acid in water. The result is in agreement with Schuhmacher et al. (2006), who found lower weight gain. Highest weight gain on $0.5 \%$ citric acid agreed with previous findings of Shen-HuiFang et al. (2005); Denil et al. (2003) and Stipkovits et al. (1992) where improved weight gain was observed with administration of citric acid in diets at $0.3,0.5$ and $0.7 \%$, respectively. The results contradict with the findings of previous researchers Pinchasov et al. (2000) where depressed weight gain was observed with application of acetic acids in diets.

Table 2. Live weight gains at different weeks in different treatments

\begin{tabular}{|c|c|c|c|c|c|c|}
\hline \multirow{2}{*}{ Age (weeks) } & \multicolumn{4}{|c|}{ Dietary treatments } & \multirow{2}{*}{ SEM } & \multirow{2}{*}{ Level of Sig } \\
\hline & A & $B$ & $\mathrm{C}$ & $\mathrm{D}$ & & \\
\hline Initial weight & $46.2 \pm 0.59$ & $46.1 \pm 0.56$ & $46.4 \pm 0.28$ & $46.1 \pm 0.33$ & 0.37 & \\
\hline 1 & $84.5 \pm 4.37^{a}$ & $88.7 \pm 1.64^{a}$ & $73.1 \pm 3.32^{b}$ & $70.3 \pm 2.03^{b}$ & 2.61 & * \\
\hline 2 & $210.3 \pm 12.19^{a}$ & $219.8 \pm 11.48^{\mathrm{a}}$ & $175.0 \pm 4.37^{b}$ & $176.6 \pm 7.84^{b}$ & 7.72 & * \\
\hline 3 & $286.4 \pm 5.89^{\text {ab }}$ & $299.2 \pm 15.19^{a}$ & $247.6 \pm 3.71^{\mathrm{c}}$ & $281.0 \pm 3.82^{b}$ & 6.10 & * \\
\hline 4 & $396.8 \pm 13.63^{b}$ & $447.2 \pm 24.06^{a}$ & $368.5 \pm 28.51^{b}$ & $372.2 \pm 9.62^{b}$ & 16.78 & * \\
\hline 5 & $403.5 \pm 23.97^{c}$ & $451.5 \pm 16.72^{b}$ & $424.7 \pm 26.21^{\mathrm{bc}}$ & $507.9 \pm 2.90^{\mathrm{a}}$ & 16.79 & * \\
\hline $0-4$ & $977.9 \pm 22.27^{b}$ & $1054.0 \pm 20.86^{a}$ & $864.2 \pm 24.77^{c}$ & $900.1 \pm 13.85^{\mathrm{C}}$ & 17.11 & * \\
\hline $0-5$ & $1381.4 \pm 9.88^{b}$ & $1506.3 \pm 4.16^{a}$ & $1289.0 \pm 19.86^{\mathrm{C}}$ & $1408.0 \pm 19.21^{b}$ & 12.25 & * \\
\hline $\begin{array}{l}\text { Final body } \\
\text { weight (g) }\end{array}$ & $1427.6 \pm 10.15^{b}$ & $1552.4 \pm 4.12^{\mathrm{a}}$ & $1335.4 \pm 20.09^{c}$ & $1454.1 \pm 19.09^{b}$ & 12.09 & * \\
\hline
\end{tabular}

$\mathrm{A}=$ Control diet; $\mathrm{B}=$ Control diet $+0.5 \%$ citric acid; $\mathrm{C}=$ Control diet $+0.5 \%$ acetic acid; $\mathrm{D}=$ Control diet $+0.5 \%$ citric acid $+0.5 \%$ acetic acid; $\pm=$ Standard deviation; SEM $=$ Standard Error Mean; Figure having different superscript in the same row differ significantly $(P<0.05) ; *=5 \%$ level of significance; NS= non significant.

\section{Feed intake}

The average feed intake of birds fed on different diets is shown in Table 3. It is evident that average feed intake was lower in treatment $A$ and higher in treatment $D$ and differed statistically $(\mathrm{P}<0.05)$ only at $2^{\text {nd }}$ and $3^{\text {rd }}$ week of age. These results contradict with the finding of previous researchers (Darko et al., 1991; Frigg et al., 1983 and Stipkovits et al., 1992) where depressed feed intake was observed. During (0-4 weeks) of age feed intake was the highest in treatment B (1787.00g) and the lowest in treatment C (1681.00g). During (0-5 weeks) of age feed intake was the highest in treatment B (3118.56g) and the lowest in treatment $A(2913.16 \mathrm{~g})$ but difference was non-significant $(P>0.05)$. The lower feed intake in treatment $C$ was accompanied by retarded growth to be the consequence of depressed water intake by the application of acetic acid in water. 
Table 3. Feed intake (g) at different weeks of experimental birds in different treatments

\begin{tabular}{|c|c|c|c|c|c|c|}
\hline \multirow{2}{*}{$\begin{array}{c}\text { Age } \\
\text { (weeks) }\end{array}$} & \multicolumn{4}{|c|}{ Dietary treatments } & \multirow[t]{2}{*}{ SEM } & \multirow[t]{2}{*}{ Level of Sig } \\
\hline & A & B & $\mathrm{C}$ & $\mathrm{D}$ & & \\
\hline 1 & $122.3 \pm 1.42$ & $124.1 \pm 1.0$ & $120.0 \pm 6.19$ & $117.0 \pm 0.64$ & 2.88 & NS \\
\hline 2 & $320.9 \pm 15.94^{\mathrm{a}}$ & $325.9 \pm 5.70^{a}$ & $292.2 \pm 3.02^{b}$ & $301.1 \pm 2.94^{b}$ & 7.05 & * \\
\hline 3 & $514.5 \pm 14.61^{b c}$ & $532.9 \pm 7.86^{\mathrm{ab}}$ & $499.1 \pm 22.62^{C}$ & $561.1 \pm 14.70^{a}$ & 13.02 & * \\
\hline 4 & $738.2 \pm 39.24$ & $804.4 \pm 39.49$ & $769.9 \pm 58.60$ & $801.9 \pm 13.26$ & 33.56 & NS \\
\hline 5 & $1217.2 \pm 105.67$ & $1331.2 \pm 84.39$ & $1348.8 \pm 166.65$ & $1320.8 \pm 12.64$ & 87.58 & NS \\
\hline $0-4$ & $1696.0 \pm 70.46$ & $1787.0 \pm 42.69$ & $1681.0 \pm 72.30$ & $1781.0 \pm 30.81$ & 46.62 & NS \\
\hline $0-5$ & $2913.2 \pm 142.90$ & $3118.6 \pm 126.99$ & $3029.9 \pm 237.88$ & $3101.9 \pm 106.8$ & $\begin{array}{c}125.2 \\
0\end{array}$ & NS \\
\hline
\end{tabular}

$\mathrm{A}=$ Control diet; $\mathrm{B}=$ Control diet $+0.5 \%$ citric acid; $\mathrm{C}=$ Control diet $+0.5 \%$ acetic acid; $\mathrm{D}=$ Control diet $+0.5 \%$ citric acid $+0.5 \%$ acetic acid; $\pm=$ Standard deviation; SEM $=$ Standard Error Mean; Figure having different superscript in the same row differ significantly $(P<0.05) ;{ }^{*}=5 \%$ level of significance; NS= non significant.

\section{Feed conversion}

The effect of organic acid supplementation on feed conversion is presented in Table 4. It is evident that FCR differ significantly $(P<0.05)$ among treatments at all ages. Better feed conversion was found in treatment $B$ and lower in treatment $C$ during $0-5$ weeks of age. The highest feed conversion on the administration of citric acid was in agreement with the findings of Afsharmanesh et al. (2005) who found higher feed conversion with the administration of citric acid in poultry.

Table 4. Feed conversion ratios of birds in different treatments

\begin{tabular}{|c|c|c|c|c|c|c|}
\hline \multirow{2}{*}{$\begin{array}{c}\text { Age } \\
\text { (weeks) }\end{array}$} & \multicolumn{4}{|c|}{ Dietary treatments } & \multirow[t]{2}{*}{ SEM } & \multirow[t]{2}{*}{ Level of significance } \\
\hline & A & B & $\mathrm{C}$ & D & & \\
\hline $0-2$ & $1.5 \pm 0.02^{b}$ & $1.5 \pm 0.06^{b}$ & $1.7 \pm 0.09^{a}$ & $1.7 \pm 0.08^{\mathrm{a}}$ & 0.281 & * \\
\hline $0-3$ & $1.7 \pm 0.03^{b}$ & $1.6 \pm 0.01^{b}$ & $1.8 \pm 0.04^{\mathrm{a}}$ & $1.9 \pm 0.05^{\mathrm{a}}$ & 0.630 & * \\
\hline $0-4$ & $1.7 \pm 0.03^{b}$ & $1.7 \pm 0.01^{b}$ & $1.9 \pm 0.04^{a}$ & $1.9 \pm 0.04^{\mathrm{a}}$ & 0.630 & * \\
\hline $0-5$ & $2.1 \pm 0.12^{b}$ & $2.1 \pm 0.08^{b}$ & $2.4 \pm 0.16^{a}$ & $2.2 \pm 0.01^{\mathrm{ab}}$ & 0.089 & * \\
\hline
\end{tabular}

$\mathrm{A}=$ Control diet; $\mathrm{B}=$ Control diet $+0.5 \%$ citric acid; $\mathrm{C}=$ Control diet $+0.5 \%$ acetic acid; $\mathrm{D}=$ Control diet $+0.5 \%$ citric acid $+0.5 \%$ acetic acid; $\pm=$ Standard deviation; SEM $=$ Standard Error Mean; Figure having different superscript in the same row differ significantly $(P<0.05) ; *=5 \%$ level of significance

\section{Carcass characteristics}

\section{Organs weight}

It is evident from the Table 5 that dressing percentage for treatment $A, B, C$ and $D$ were $54.98,55.40,51.90$ and $56.80 \%$ respectively which did not differ significantly $(P>0.05)$. The results are in well agreement with the previous findings (Kahraman et al., 1997) where no significant effect was observed. The highest (56.7\%) value for carcass yield was found in treatment $\mathrm{D}$ and the lowest (51.8\%) value was found in treatment $\mathrm{C}$. 
Table 5. Carcass characteristics of broilers in different treatments

\begin{tabular}{|c|c|c|c|c|c|c|}
\hline \multirow[t]{2}{*}{ Parameters } & \multicolumn{4}{|c|}{ Dietary treatments } & \multirow[t]{2}{*}{ SEM } & \multirow[t]{2}{*}{ Level of Sig. } \\
\hline & $A$ & $B$ & $C$ & $D$ & & \\
\hline Live weight $(\mathrm{g})$ & $1146.7 \pm 152.0$ & $1300.0 \pm 0.00$ & $1150.0 \pm 132.0$ & $1150.0 \pm 150.0$ & 102.74 & NS \\
\hline \multicolumn{7}{|c|}{ Organ weights (\% live weight) } \\
\hline Killed weight & $89.6 \pm 3.56$ & $89.9 \pm 3.67$ & $89.2 \pm 2.63$ & $89.9 \pm 1.42$ & 2.43 & NS \\
\hline Shank weight & $4.6 \pm 0.66$ & $4.9 \pm 0.44$ & $4.9 \pm 0.43$ & $4.9 \pm 0.13$ & 0.373 & NS \\
\hline Head weight & $3.9 \pm 0.45$ & $3.9 \pm 0.00$ & $3.5 \pm 0.38$ & $3.2 \pm 0.31$ & 0.851 & NS \\
\hline Giblet weight & $7.3 \pm 0.60$ & $7.2 \pm 0.80$ & $7.3 \pm 0.81$ & $7.2 \pm 0.59$ & 0.578 & NS \\
\hline Skin weight & $16.2 \pm 1.12$ & $15.1 \pm 1.24$ & $15.7 \pm 1.32$ & $14.8 \pm 0.19$ & 0.873 & NS \\
\hline Visceral weight & $7.8 \pm 0.95$ & $7.7 \pm 0.39$ & $7.3 \pm 0.35$ & $7.7 \pm 0.36$ & 0.466 & NS \\
\hline Carcass yield & $54.98 \pm 2.24$ & $55.4 \pm 2.66$ & $51.9 \pm 4.63$ & $56.8 \pm 3.08$ & 2.67 & NS \\
\hline
\end{tabular}

$\mathrm{A}=$ Control diet; $\mathrm{B}=$ Control diet $+0.5 \%$ citric acid; $\mathrm{C}=$ Control diet $+0.5 \%$ acetic acid; $\mathrm{D}=$ Control diet $+0.5 \%$ citric acid $+0.5 \%$ acetic acid; SEM $=$ Standard Error Mean; NS= non significant.

In dietary treatment $\mathrm{D}$ the dressing yield was improved by about $3.46 \%$ when compared with the control group. This result did not agree with previous findings of Garcia et al. (2000) who found decrease carcass yield. The increased dressing yield on dietary treatment $D$ might be due to increasing live weight on $0.5 \%$ citric and acetic acid. The result partially agreed with Sapra and Mehta (1990), who found increased edible meat yield with increasing body weight. Per cent giblet weight was not affected by dietary treatments. Weight of shank in different treatments did not differ significantly $(P>0.05)$ among different dietary treatments. Head weight was similar in all treatments. Skin and feather weight per cent did not differ significantly $(P>0.05)$ among treatments.

\section{Economy of broiler production}

The production cost of broiler in different dietary treatments is shown in Table 6 . The feed cost was highest (Tk.1559.49) in treatment D and the lowest (Tk. 1464.48) in treatment A (control group). The addition of $0.5 \%$ citric acid in diets and $0.5 \%$ acetic acid in water resulted in an increased feed cost in treatment $B, C$ and $D$ against treatment $A$ (Control group). Cost per kg live weight of broiler was the highest in treatment $C$ (Tk. 69.21) followed by treatment A (60.35), B (60.70) and D (63.77) respectively. Net profit per $\mathrm{kg}$ live broiler was the highest in treatment $A$ (Tk. 19.70) followed by treatment $B$ (Tk 19.30), C (Tk.10.70) and D (Tk.16.20) respectively. The highest total net profit was observed in dietary treatment $B$ and the lowest total net profit was observed in treatment $C$ as compare to treatment $A$ (Control group).

Table 6. Production cost of broiler in different dietary treatments

\begin{tabular}{|l|r|r|r|r|}
\hline \multirow{2}{*}{ Parameters } & \multicolumn{4}{|c|}{ Dietary treatments } \\
\cline { 2 - 5 } & \multicolumn{1}{|c|}{ A } & \multicolumn{1}{c|}{ B } & \multicolumn{1}{c|}{ D } \\
\hline Total feed cost & 1464.48 & 1568.04 & 1523.30 & 1559.49 \\
\hline Total chick cost & 378 & 378 & 378 & 378 \\
\hline Management cost $^{1}$ & 484.59 & 537.35 & 502.68 & 566.20 \\
\hline Total acid cost & - & 60.31 & 90.77 & 156.27 \\
\hline Total production cost (Tk.) & 2327.07 & 2543.73 & 2494.75 & 2503.69 \\
\hline Total production cost (Tk.)/kg live weight & 60.35 & 60.70 & 69.21 & 63.77 \\
\hline Total sale priced (Tk.) & 3084.48 & 3352.32 & 2883.60 & 3140.64 \\
\hline Total net profit (Tk.) & 757.48 & 808.59 & 388.25 & 636.95 \\
\hline Net profit (Tk.)/kg live weight & 19.70 & 19.30 & 10.70 & 16.20 \\
\hline
\end{tabular}

$\mathrm{A}=$ Control diet; $\mathrm{B}=$ Control diet $+0.5 \%$ citric acid; $\mathrm{C}=$ Control diet $+0.5 \%$ acetic acid; $\mathrm{D}=$ Control diet $+0.5 \%$ citric acid $+0.5 \%$ acetic acid

NB-cost of feed calculated based on ingredients and test substances added.

${ }^{1}$ Management cost assuming approximately $33 \%$ of total cost (except chick cost). 
It may be concluded that supplementation of $0.5 \%$ citric acid $(B)$ in the diet showed positive effect on live weight, feed intake and feed conversion efficiency with no detrimental effect on carcass characteristics.

\section{References}

Adams, C. 1999. Poultry and dietary acids. Feed Int., 20 (19): 1370-1372.

Afsharmanesh, M. and Pourreza, J. 2005. Effects of calcium, citric acid, ascorbic acid, vitamin $D_{3}$ on the efficacy of microbial phytase in broiler starters fed wheat based diets. Internat J. Poult Sci., 4(6): 418-424.

Callesen, J. 1999. Commercial feed products and feed mixes for piglets. Lansuvalget for Svin, Report. 409, January: 20-21.

Darko, S., Jelena, P.G. Zdravka, B. and Kanizaj, V. 1991. Effect of therapeutic level of tiamutin on higher toxicity of monensin in weaned pigs. Veterinarski arhiv., 61(2): 67-82.

Denli, M., Okan, F. and Celik, K. 2003. Effect of dietary probiotic, organic acid and antibiotic supplementation to diets on broiler performance and carcass yield. Pak. J. Nutr., 2(2): 89-91.

Estieve, G,E., Brufau, J. and Perez, A.K. 1997. Bioefficacy of enzyme preparations containing beta-glucanse and xylanase activities in broiler diets based on barley or heat in combination with flavomycin. Poult Sci., 76: 1726-1737.

Frigg, M., Broz, J, and Weber, G. 1983. Compatibility studies of ionophore antcoccidials with various antibioitics and chemotherapeutics in broiler chicks. Arch. Gelflugelk., 47(5): 213-220.

Garcia, R.G., Ariki, J., Moraes, V.M.B., Kronka, S.N., Borges, S.A., Murata, L.S. and Campos, V.A. 2000. Isolated or combined action of organic acids and growth promoter in broiler rations. Revista Brasileira de Ciencia Avicola., 2(2): 149-154.

Hyden, M. 2000. Protected acid additives. Feed Internat., 7: 14-16.

Kahraman, R., Abas, I., Bostan, K., Tanor, A., Kocabagli, N. and Alp, M. 1997. Effects of organic acids and yeast culture on performance, ileum $\mathrm{pH}$ and Enterobacteriaceae population of broilers. Pendik Veteriner Mikrobiyoloji Dergisi. 28(2): 171-180.

Owings, W.J., Reynolds, D.L., Hasiak, R.J. and Ferket, P.R. 1990. Influence of dietary supplementation with Streptococcus faecium M-74 on broiler body weight feed conversion; carcass characteristics and intestinal microbial colonization. Poult. Sci., 69: 1257-1264.

Patten, J.D. and Waldroup, P.W. 1988. The use of organic acids in broiler diets. Poult. Sci., 67: 1182- 1187.

Pinchasov, Y. and Elmalich, S. 2000. Broiler chick responses to anorectic agent: dietary acetic and propionic acids and the digestive system. Faculty of Agriculture, Hervew University of Jerusalem, Rehovot, Israel. (http:/l www.ncbi.nlm.nih.gov/sites/entrez).

Samik, K.P., Gobinda, H., Manas, K.M. and Gautam, S. 2007. Effect of organic acid salt on the performance and gut health of broiler chicken. J. Poult. Sci., 44: 389-395.

Sapra, K.I. and Mehta, R.K. 1990. A comparative study on addition Livol (Hervol growth promoter) and some chemical growth promoters in the diet of broiler chicks. Indian J. Anim. Prod. and Manag., 6: (2), 115-118.

Schuhmacher, K., Bafundo, W., Islam, K.M.S., Aupperle, H., Glaser, R., Schoon, H.A. and Gropp, J.M. 2006. Tiamutin and semduramicin: Effects of Simultaneous Administration on Performance and Health of Growing Broiler Chickens. Poult. Sci., 85: 441-446

Shane, S. 1999. The antibiotics issue. Poult. Internat., 38: 46- 50.

Shen-HuiFang, Han-ChuiWang and Du-BingWang. 2005. Effects of citric acid on production performance of Three Yellow chicken. China Poult., 27(16): 14-15.

Skinner, J.J., Izat, A.L. and Waldroup, P.W. 1991. Research Note: Fumaric acid enhances performance of broiler chicken. Poult. Sci., 70: 1444- 1447

Stipkovits, L., Csiba, E., Laber, G. and Bruch, D.G.S. 1992. Simultaneous treatment of chickens with salinomycin and tiamutin in feed. Avian Dis., 36: 11-16.

Wiseman J. 1987. Feeding of Non-ruminant Livestock. Butterworths and Co.Ltd., London. p. 10. 